\title{
Detection of Zika virus RNA in whole blood of imported Zika virus disease cases up to 2 months after symptom onset, Israel, December 2015 to April 2016
}

Y Lustig ${ }^{1}$, E Mendelson ${ }^{12}$, N Paran ${ }^{3}$, S Melamed ${ }^{3}$, E Schwartz 4

1. Central Virology Laboratory, Ministry of Health, Tel-Hashomer, Israel

2. School of Public Health, Sackler Faculty of Medicine, Tel-Aviv Úniversity, Israel

3. Israel Institute for Biological Research, Ness-Ziona, Israel

4. Institute of Tropical Medicine, Sheba Medical Ctr. Tel Hashomer, Israel

Correspondence: Yaniv Lustig (yaniv.lustig@sheba.health.gov.il)

Citation style for this article:

Lustig Y, Mendelson E, Paran N, Melamed S, Schwartz E. Detection of Zika virus RNA in whole blood of imported Zika virus disease cases up to 2 months after

symptom onset, Israel, December 2015 to April 2016. Euro Surveill. 2016;21(26):pii=30269. DOI: http://dx.doi.org/10.2807/1560-7917.ES.2016.21.26.30269

Zika virus RNA presence in serum, whole-blood and urine samples from six Israeli travellers symptomatic for Zika virus disease was examined. Whole-blood samples were positive for as late as 2 months ( 58 days) post-symptom onset, longer than for urine (26 days) and serum ( 3 days). These findings suggest the utility of whole blood in Zika infection diagnosis.

The ongoing Zika epidemic was recently declared by the World Health Organization as a Public Health Emergency of International Concern [1]. Laboratory diagnosis of Zika virus infection is thus important, but remains however challenging, due to a limited time window of possible virus detection, whereby patients tested more than one to two weeks post-symptom onset are difficult to diagnose [2-4]. There is therefore a need for an accurate diagnostic approach that will prolong the diagnostic period. We examined the utility of whole blood (WB) samples for detecting Zika virus RNA, compared with serum, or urine samples. Our findings suggest that Zika virus-RNA can be found in WB for a longer period than in serum and urine. More importantly, we show that Zika virus RNA can be identified in WB as late as 2 months after the onset of Zika virus disease (ZVD) symptoms.

\section{Zika virus RNA in serum, urine and whole blood}

All patients suspected of being infected with Zika virus were diagnosed at the National Center for Zoonotic Viruses, which is part of the Central Virology Laboratory (CVL) of the Israel Ministry of Health and is the reference laboratory for the diagnosis of arboviral infections in Israel. From December 2015 to April 2016, 145 patients returning to Israel after travel to Zika virus endemic areas, were respectively tested for the virus by real-time polymerase chain reaction ( $q R T-P C R$ ) on different clinical specimens. Altogether 423 tests were performed; 158 on sera, 135 on WB and 130 on urine samples. Ten samples from six patients were positive for Zika virus RNA (Table).

The six patients were aged 3 to 61 years and two of them were male. All had symptoms compatible with ZVD; fever $\left(\geq 38^{\circ} \mathrm{C}\right)$, rash, conjunctivitis and arthralgia [5]. A serum sample had initially been obtained from each patient, while a follow-up serum sample, as well as urine and WB specimens were only available for five patients.

Testing for the presence of Zika virus RNA in the respective initial serum samples was conducted for all six patients, whereby the qRT-PCR was only positive for one of these samples, which was drawn 3 days postsymptom onset. The other five initial serum samples, which were qRT-PCR negative, were drawn 5 days or more after onset of symptoms. For five initial serum samples, the amount of serum was sufficient to also investigate the presence of Zika virus antibodies by enzyme-linked immunosorbent assay (ELISA). Of these five samples, four were IgM positive, including three who were also IgG positive.

Urine was positive in three samples obtained from three patients 5 to 26 days post-symptom onset, and for these patients a second respective urine sample dated 46 days or later after the start of symptoms was negative. In contrast, all five patients with WB examined, tested positive in a total of six samples obtained 5 to 58 days post-symptom onset (Table). In two patients, WB remained positive for as long as 46 (patient 5) and 58 days (patient 4) after the onset of symptoms (Table). For patient 4, a urine sample was comparatively negative already at 10 days after the symptoms began, while for patient 5 , one urine sample obtained 26 days following the start of ZVD was 


\section{FIGURE}

Zika virus RNA load in samples obtained from infected patients after onset of Zika virus disease, Israel, December 2015-April 2016 ( $n=6$ patients)

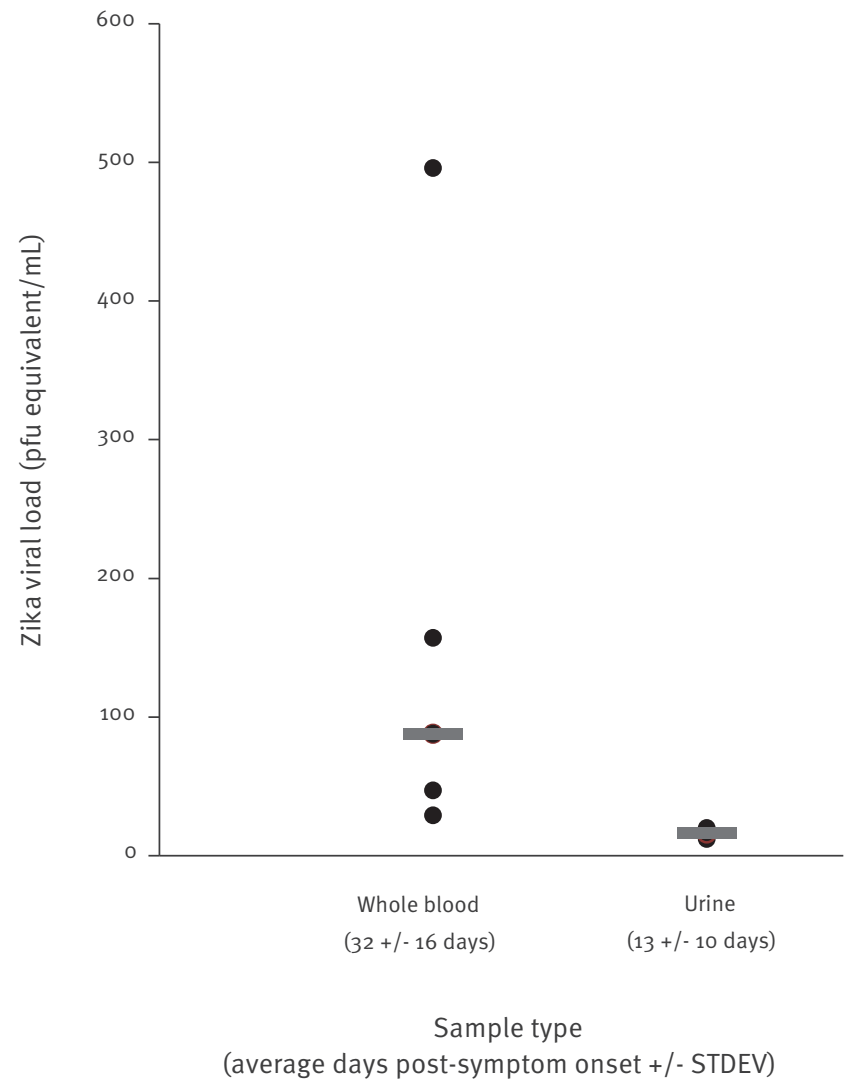

Pfu: plaque-forming units; STDEV: standard deviation.

Zika virus load in whole blood (6 samples) and urine (3 samples), as determined by real-time polymerase chain reaction (qRT$P(R)$. All qRT-PCR negative samples were excluded from viral load analysis. Horizontal bars represent the median viral loads.

positive whereas a second urine sample dated 46 days post-symptom onset was negative.

Considering all urine and WB samples found positive by qRT-PCR in the study, the median amount of Zika virus RNA was 88 plaque-forming units (pfu) equivalents/mL in WB compared with 16 pfu equivalents $/ \mathrm{mL}$ in urine, despite the fact that the WB was taken at a longer time after symptom onset (Figure), suggesting that the quantity of Zika virus RNA is substantially higher in WB.

Most importantly, sequencing of part of the precursor membrane (prM) and envelope (ENV) genes (327bp) of the Zika genome was achieved from four WB samples. Results showed Zika virus RNA sequences with high similarity to those of strains identified in the likely geographical areas of infection (Asian lineage) [6]. Unfortunately, we were not able to isolate and grow infectious virus in tissue culture.

\section{Laboratory investigations}

For Zika virus RNA detection, total nucleic acids were purified from $200 \mu \mathrm{L}$ (WB and serum), or $1 \mathrm{~mL}$ (urine) of specimens by using the NucliSENS EasyMAG system (bioMérieux, Marcy l'Etoile, France) according to the manufacturer's instructions with minor modifications. Briefly, MS2 Coliphage (10,000 copies/mL) was added to the lysis buffer to control for proper extraction and sample inhibition [7] and external lysis was performed on all samples immediately upon arrival at the CVL (which could be up to 48 hours after a sample was obtained from the patient) to inactivate the virus as recommended by the manufacturer. This was followed by nucleic acid (NA) extraction using the EasyMAG extractor. Extracted NA was eluted in $55 \mu \mathrm{L}$ elution buffer and stored at $-70^{\circ} \mathrm{C}$ pending analysis.

The ABI Prism 7500 sequence detection system (Applied Biosystems, Foster City, CA, US) was used for the amplification and detection of the MS2 and Zika RNA by qRT-PCR as previously described $[7,8]$. Briefly, for MS2 qRT-PCR, $5 \mu \mathrm{L}$ of RNA was added to the AgPath Mastermix (Ambion, Applied Biosystems Inc, Foster City, California), which contained 3oonM of each primer and 200nM of probe and 5-carboxy-X-rhodamine succinimidyl ester (ROX) as an internal reference dye, whereas for the Zika qRT-PCR assay, $5 \mu \mathrm{L}$ of RNA was added and the specific primer and probe set for the ENV protein gene was used as previously described [8]. qRT-PCR was performed under the following conditions: $30 \mathrm{~min}$ at $48^{\circ} \mathrm{C}, 10 \mathrm{~min}$ at $95^{\circ} \mathrm{C}$, and 50 cycles of $15 \mathrm{~S}$ at $95^{\circ} \mathrm{C}$ and $1 \mathrm{~min}$ at $60^{\circ} \mathrm{C}$. Quantification of Zika virus NA in the tested samples was based on titration of Zika MR-766, which was kindly supplied by R. Lanciotti from the Division of Vector Borne Diseases, Centers for Disease Control and Prevention, Fort-Collins, Co, United States. The limit of detection of the Zika qRTPCR method was between 10 and 20 pfu equivalents/ $\mathrm{mL}$, in WB, urine, and serum specimens.

For sequencing of Zika RNA, a 327 fragment from the prM and ENV genes was amplified by reverse-transcription $P C R$ using primers ZIKV 835 (5'-TTGGTCATGATACTGCTGATTGC-3') and ZIKV $1162 \mathrm{C}$ (5'-CCACTAACGTTCTTTTGCAGACAT-3') [8] and sequenced on an ABI 3500 Genetic Analyzer (Applied Biosystems, Foster City, CA, United States) using an ABI PRISM BigDye Terminator Cycle Sequencing kit (Applied Biosystems) [6].

Frozen whole blood (obtained 5, 26, 34 and 58 days post-symptom onset) and urine (obtained 5, 10, and 26 days post-symptom onset) samples were diluted (1:10) in modified Eagle medium (MEM; Biological Industries) supplemented with $2 \%$ heat-inactivated fetal bovine serum (FBS), glutamine, non-essential amino acids and penicillin-streptomycin, overlaid on Vero c1008 (E6) for 7 days at $37^{\circ} \mathrm{C}$ in $5.0 \% \mathrm{CO}_{2}$ followed by additional 7 days on fresh cells. 
Zika RNA detection and quantification in samples from patients returning from Zika virus endemic areas, Israel, December 2015-April 2016 ( $n=6$ patients)

\begin{tabular}{|c|c|c|c|c|c|c|c|c|}
\hline \multirow[b]{3}{*}{$\begin{array}{l}\text { Patient } \\
\text { number }\end{array}$} & \multirow[b]{3}{*}{$\begin{array}{l}\text { Probable } \\
\text { country of } \\
\text { exposure }\end{array}$} & \multicolumn{4}{|c|}{ First set of samples } & \multirow{2}{*}{\multicolumn{3}{|c|}{$\begin{array}{c}\text { Second set of samples } \\
\text { qRT-PCR }\end{array}$}} \\
\hline & & \multirow[b]{2}{*}{$\begin{array}{l}\text { Serology } \\
\text { results } \\
\text { (IgM/lgG) }\end{array}$} & \multicolumn{3}{|c|}{ qRT-PCR } & & & \\
\hline & & & $\begin{array}{c}\text { Serum result, } \\
\text { days from } \\
\text { symptom onset } \\
\text { (pfu equivalent/ } \\
\text { ml) }\end{array}$ & $\begin{array}{c}\text { Urine result, } \\
\text { days from } \\
\text { symptom onset } \\
\text { (pfu equivalent/ } \\
\text { ml) }\end{array}$ & $\begin{array}{l}\text { WB result, days } \\
\text { from symptom } \\
\text { onset (pfu } \\
\text { equivalent } / \mathrm{ml} \text { ) }\end{array}$ & $\begin{array}{c}\text { Serum result, } \\
\text { days from } \\
\text { symptom onset } \\
\text { (pfu equivalent/ } \\
\text { ml) }\end{array}$ & $\begin{array}{l}\text { Urine result, } \\
\text { days from } \\
\text { symptom } \\
\text { onset (pfu } \\
\text { equivalent/ml) }\end{array}$ & $\begin{array}{l}\text { WB result, } \\
\text { days from } \\
\text { symptom } \\
\text { onset (pfu } \\
\text { equivalent/ml) }\end{array}$ \\
\hline 1 & Colombia & ND & Pos 3, (496) & ND & ND & ND & ND & ND \\
\hline 2 & Colombia & Pos/Pos & $\mathrm{Neg}, 5$ (NA) & Pos, 5 (16) & Pos, 5 (88) & Neg, 120 (NA) & Neg, 120 (NA) & Neg, 120 (NA) \\
\hline 3 & Colombia & Pos/Pos & Neg, 10 (NA) & Pos, 10 (12) & Pos, $34^{b}$ (157) & Neg, 78 (NA) & Neg, 78 (NA) & Neg, 78 (NA) \\
\hline 4 & Vietnam & Pos/Neg & Neg, $10(N A)$ & Neg, 10 (NA) & Pos, $58^{\mathrm{b}}(88)$ & Neg, 79 (NA) & Neg, 79 (NA) & Neg, 79 (NA) \\
\hline 5 & $\begin{array}{l}\text { Dominican } \\
\text { Republic }\end{array}$ & Pos/Pos & Neg, 26 (NA) & Pos, 26 (20) & Pos, 26 (47) & Neg, 46 (NA) & Neg, 46 (NA) & Pos, 46 (29) \\
\hline 6 & Mexico & $\mathrm{Neg} / \mathrm{Neg}$ & Neg, 26 (NA) & Neg, 26 (NA) & Pos, 26 (496) & Neg, 48 (NA) & Neg, 48 (NA) & Neg, 48 (NA) \\
\hline
\end{tabular}

F: female; M: male; NA: not applicable; ND: not performed due to lack of material; Neg: negative; Pos: positive; pfu: plaque-forming unit; qRTPCR: quantitative real-time polymerase chain reaction; WB: whole blood.

a Serology performed by enzyme-linked immunosorbent assay (ELISA; Euroimmun).

${ }^{b}$ WB samples were not obtained at the same time as urine and serum samples.

Serological testing for Zika virus was performed by using an ELISA IgM and IgG kit (Euroimmun AG, Germany) which detects antibodies against the Zika nonstructural protein $\mathrm{NS}_{1}$ [9].

\section{Discussion}

Zika virus is a mosquito-borne flavivirus that has spread in the last months throughout tropical and subtropical areas of the Americas causing a widespread epidemic [10]. As it is strongly suspected that infection with this virus may in some cases result in neurological disorders as well as congenital abnormalities, accurate diagnosis is extremely important [1]. Due to the extensive cross-reactivity between Zika virus and other flaviviruses in serology, which can lead to false positive results, serological assays have substantial limitations [8]. Currently qRT-PCR is the most reliable test, but the period in which zika virus RNA can be identified after ZVD manifestation is restricted. Following symptom onset, qRT-PCR detects Zika virus RNA for only up to 5 days in serum [4], and up to 10 to 20 days in urine [2]. The use of saliva samples has been recently shown to increase the rate of molecular detection of Zika virus RNA in the acute phase of the disease but did not enlarge the detection period window [3]. Here we find that Zika virus RNA is present for a substantially longer time period in WB than in serum or urine and may even persist for up to 2 months post-symptom onset.

Despite the limited number of samples tested, the study clearly shows the advantage of WB testing. In sera, we could not detect Zika virus RNA more than 5 days after onset of symptoms, and in urine, the latest detection of such RNA post-symptom onset for three of five samples was 26 days. In contrast, WB was Zika virus-RNA positive in all samples collected within the first month post-symptom onset, in three of four samples in the second month, and in none when testing after 2 months.

The use of WB for flavivirus RNA detection is not new. Several studies, have demonstrated that a large proportion of West Nile virus (WNV) is bound to red blood cells (RBCs) and have shown that WNV RNA concentrations in seropositive donations are 10 -fold higher in WB than in plasma and persist for a much longer period of time [11-13]. For diagnostic purposes, we demonstrated very recently that WNV RNA can be identified by qRTPCR in $86.8 \%$ of WB samples but only in $26 \%$ of serum samples during acute infection [14]. A higher detection rate in WB compared with serum or plasma has also been described previously for dengue virus [15]. Our current study suggests that Zika virus presents similarities to other flaviviruses in this respect.

Virus isolation was unsuccessful for all WB and urine samples most probably because of the low amount of virus that was present in the samples. However, it is also possible that the virus was not viable due to the time that has passed from symptoms onset until sample collection. Future studies should investigate the possibility, raised by our study that Zika virus could circulate in the blood of infected patients for up to 2 months. Diagnosis of recent Zika virus infection is important even after a patient's full recovery, not only because of the possible risk to the fetus in pregnant women, but also considering reports that sexual transmission of the virus from men to women has likely occurred [16] and the finding of the virus in semen for several weeks following infection $[17,18]$. Although our study establishes the utility of WB in the routine diagnosis of Zika infection, more studies are required to precisely determine the time frame of presence as 
well as the amounts of Zika virus RNA in WB following infection.

\section{Acknowledgements}

We thank Robert Lanciotti from the Division of vector Borne Diseases, Centers for Disease Control and Prevention, FortCollins, Co, USA for the Zika MR-766 virus and guidance in establishing the qRT-PCR assay and Musa Hindiyeh from the Central Virology Laboratory of the Israel Ministry of Health for the Zika qRT-PCR evaluation.

\section{Conflict of interest}

None declared.

\section{Authors' contributions}

Y.L. contributed to the study design, performed the molecular experiments, analysed the data, wrote and edited the manuscript, E.M contributed to the study design, edited the manuscript and provided critical review of the manuscript. N.P. and S.H. set up and performed the virus isolation experiments and E.S examined the patients, coordinated the work, analysed the data, contributed to the study design and provided critical review of the manuscript.

\section{References}

1. World Health Organization (WHO). WHO Director-General summarizes the outcome of the Emergency Committee regarding clusters of microcephaly and Guillain-Barré syndrome. Geneva: WHO; 1 Feb 2016. Available from: http://www.who.int/mediacentre/news/statements/2016/ emergency-committee-zika-microcephaly/en/

2. Gourinat AC, O'Connor O, Calvez E, Goarant C, DupontRouzeyrol M. Detection of Zika virus in urine.Emerg Infect Dis. 2015;21(1):84-6. DOI: 10.3201/eid2101.140894 PMID: 25530324

3. Musso D, Roche C, Nhan TX, Robin E, Teissier A, Cao-Lormeau VM. Detection of Zika virus in saliva.J Clin Virol. 2015;68:53-5 DOI: 10.1016/j.jcv.2015.04.021 PMID: 26071336

4. Bingham AM, Cone M, Mock V, Heberlein-Larson L, Stanek D, Blackmore C, et al. Comparison of Test Results for Zika Virus RNA in Urine, Serum, and Saliva Specimens from Persons with Travel-Associated Zika Virus Disease - Florida, 2016. MMWR Morb Mortal Wkly Rep. 2016;65(18):475-8. DOI: 10.15585/ mmwr.mm6518e2 PMID: 27171533

5. Meltzer E, Leshem E, Lustig Y, Gottesman G, Schwartz E. The clinical spectrum of Zika virus in returning travelers. Am J Med. 2016; So002-9343(16)30536-8.PMID: 27260832

6. Meltzer E, Lustig Y, Leshem E, Levy R, Gottesman G, Weissmann R, et al. Zika Virus Disease in Traveler Returning from Vietnam to Israel. Emerg Infect Dis. 2016;22(8). DOI: 10.3201/eid2208.160480 PMID: 27331627

7. Shulman LM, Hindiyeh M, Muhsen K, Cohen D, Mendelson E, Sofer D. Evaluation of four different systems for extraction of RNA from stool suspensions using MS-2 coliphage as an exogenous control for RT-PCR inhibition.PLoS One. 2012;7(7):e39455. DOI: 10.1371/journal.pone.0039455 PMID: 22815706

8. Lanciotti RS, Kosoy OL, Laven JJ, Velez JO, Lambert AJ, Johnson AJ, et al. Genetic and serologic properties of Zika virus associated with an epidemic, Yap State, Micronesia, 2007. Emerg Infect Dis. 2008;14(8):1232-9. DOI: 10.3201/ eid1408.080287 PMID: 18680646

9. Huzly D, Hanselmann I, Schmidt-Chanasit J, Panning M. High specificity of a novel Zika virus ELISA in European patients after exposure to different flaviviruses. Euro Surveill. 2016;21(16):30203. DOI: 10.2807/1560-7917 ES.2016.21.16.30203 PMID: 27126052

10. Fauci AS, Morens DM. Zika Virus in the Americas--Yet Another Arbovirus Threat.N Engl J Med. 2016;374(7):601-4. DOI: 10.1056/NEJMp1600297 PMID: 26761185

11. Lai L, Lee TH, Tobler L, Wen L, Shi P, Alexander J, et al. Relative distribution of West Nile virus RNA in blood compartments: implications for blood donor nucleic acid amplification technology screening. Transfusion. 2012;52(2):447-54. DOI: 10.1111/j.1537-2995.2011.03289.x PMID: 21827506

12. Lanteri MC, Lee TH, Wen L, Kaidarova Z, Bravo MD, Kiely NE, et al. West Nile virus nucleic acid persistence in whole blood months after clearance in plasma: implication for transfusion and transplantation safety. Transfusion. 2014;54(12):3232-41. DOI: $10.1111 /$ trf.12764 PMID: 24965017

13. Rios M, Daniel S, Chancey C, Hewlett IK, Stramer SL. West Nile virus adheres to human red blood cells in whole blood. Clin Infect Dis. 2007;45(2):181-6. DOI: $10.1086 / 518850$ PMID: 17578776

14. Lustig Y, Mannasse B, Koren R, Katz-Likvornik S, Hindiyeh $M$, Mandelboim $M$, et al. Superiority of West Nile Virus RNA detection in whole blood for diagnosis of acute infection. J Clin Microbiol. 2016;JCM.01283-16. DOI: 10.1128/JCM.01283-16 PMID: 27335150

15. Klungthong C, Gibbons RV, Thaisomboonsuk B, Nisalak A, Kalayanarooj S, Thirawuth V, et al. Dengue virus detection using whole blood for reverse transcriptase PCR and virus isolation. J Clin Microbiol. 2007;45(8):2480-5. DOI: 10.1128/ JCM.00305-07 PMID: 17522268

16. Frank C, Cadar D, Schlaphof A, Neddersen N, Günther S, Schmidt-Chanasit J, et al. Sexual transmission of Zika virus in Germany, April 2016. Euro Surveill. 2016;21(23):30252. DOI: 10.2807/1560-7917.ES.2016.21.23.30252 PMID: 27311329

17. Musso D, Roche C, Robin E, Nhan T, Teissier A, Cao-Lormeau VM. Potential sexual transmission of Zika virus.Emerg Infect Dis. 2015;21(2):359-61. DOI: 10.3201/eid2102.141363 PMID: 25625872

18. Reusken C, Pas S, GeurtsvanKessel C, Mögling R, van Kampen J, Langerak T, et al. Longitudinal follow-up of Zika virus RNA in semen of a traveller returning from Barbados to the Netherlands with Zika virus disease, March 2016. Euro Surveill. 2016;21(23):30251. DOI: 10.2807/1560-7917. ES.2016.21.23.30251 PMID: 27313200

\section{License and copyright}

This is an open-access article distributed under the terms of the Creative Commons Attribution (CC BY 4.0) Licence. You may share and adapt the material, but must give appropriate credit to the source, provide a link to the licence, and indicate if changes were made.

This article is copyright of the authors, 2016. 